\title{
Pediatric Castleman disease
}

INSERM

\section{Source}

INSERM. (1999). Orphanet: an online rare disease and orphan drug data base. Pediatric Castleman disease. ORPHA:93682

Pediatric Castleman disease ( $P C D)$ is a form of Castleman disease (CD, see this term) with a predominant occurrence in teenagers which is either asymptomatic or manifest by systemic (such as fever, anemia, fatigue and failure to thrive) or compressive symptoms. 